\title{
WYKORZYSTANIE TECHNIK ZARZĄDZANIA DO IDENTYFIKACJI ŹRÓDŁA NIEZGODNOŚCI USZKODZEŃ MECHANICZNYCH
}

\author{
Dominika Siwiec ${ }^{1}$, Andrzej Pacana ${ }^{2}$ \\ ${ }^{1}$ Politechnika Rzeszowska im. Ignacego Łukasiewicza \\ Wydział Budowy Maszyn i Lotnictwa \\ ${ }^{2}$ Politechnika Rzeszowska im. Ignacego Łukasiewicza \\ Wydział Budowy Maszyn i Lotnictwa
}

\begin{abstract}
Streszczenie: Analizy niezgodności produktów, jak również źródeł ich powstania są szczególnie istotne w ramach zarządzania jakością produktu. Niezgodności te wystąpiły w przedsiębiorstwie produkcyjnym zlokalizowanym na Podkarpaciu. W sposób rutynowy nie udało się zidentyfikować źródła tych uszkodzeń. Dlatego uznano, że zastosowanie technik zarządzania procesem identyfikacji źródła niezgodności, tj. metoda 5W2H, diagram Pareto-Lorenza, diagram Ishikawy i metoda 5Why, umożliwi identyfikację źródła niezgodności uszkodzeń mechanicznych na froncie meblowym. Celem pracy jest wykazanie, że wybrane techniki zarząazzania procesem zidentyfikowania źródła niezgodności mają zastosowanie do wskazania źródła uszkodzeń mechanicznych. Za pomocą metody $5 \mathrm{~W} 2 \mathrm{H}$ przeanalizowano i zdefiniowano niezgodność. Diagramem Pareto-Lorenza ukazano udział uszkodzeń mechanicznych, z kolei diagramem Ishikawy wskazano potencjalne i główne przyczyny niezgodności, tj. nieodpowiednie magazynowanie wyrobów oraz złe transportowanie. Metodą 5 Why zidentyfikowano źródło powstania uszkodzeń mechanicznych, którym była nieuwaga pracowników oraz nieprzestrzeganie zasad magazynowania i transportowania wyrobów. Wykazano, że zastosowanie wybranych technik zarządzania procesem identyfikacji źródła niezgodności umożliwia wskazanie źródła uszkodzeń mechanicznych na froncie meblowym. Zaproponowana metoda może być praktykowana w różnych przedsiębiorstwach do analizy problemów z jakością wyrobów.
\end{abstract}

Słowa kluczowe: jakość, uszkodzenia mechaniczne, inżynieria mechaniczna, techniki zarządzania jakością, niezgodność

DOI: $10.17512 /$ znpcz.2020.3.04

\section{Wprowadzenie}

Kontrole jakości wyrobów w dobrze prosperujących przedsiębiorstwach występują jako proces, czyli zestaw przemyślanych, kolejno występujących po sobie działań (Jankowiak 2008, s. 53). Działania te powinny zapewnić jakość, powtarzalność i stabilność procesu (Rachwał, Wolniak 2018, s. 492), jak i umożliwić wyeliminowanie działań nie tworzących wartości dodanej dla procesu (Rosak-Szyrocka 2017, s. 41), dlatego też często odnoszą się do zarządzania i identyfikowania niezgodności wyrobu, a kolejno wskazania źródła jego powstania (Pacana i in. 2015, s. 1334;

\footnotetext{
${ }^{1}$ Dominika Siwiec, mgr inż., d.siwiec@ prz.edu.pl, ORCID: 0000-0002-6663-6621

${ }^{2}$ Andrzej Pacana, dr hab. inż. prof. PRz, app@ prz.edu.pl, ORCID: 0000-0003-1121-6352
} 
Pacana i in. 2019, s. 110, Siwiec i in. 2019, s. 1594). Wspomniane podejście procesowe odnosi się do wszystkich koncepcji projakościowego zarządzania (Sobocha-Stanuch 2014, s. 22). W związku z tym proces identyfikacji niezgodności występuje z technikami zarządzania jakością (Frąś, Frąś, Frąś 2017, s. 176). Połączenie to ma na celu nie tylko wskazać źródło niezgodności wyrobu, ale także umożliwić efektywne monitorowanie procesu (Chądzyńska, Klimecka-Tatar 2017, s. 32), dzięki czemu możliwe jest odpowiednie zarządzanie niezgodnością, w tym zastosowanie odpowiednich działan doskonalących. Z kolei działania doskonalące na rzecz poprawy jakości wyrobów mają na celu eliminację lub redukcję niezgodności (Hamrol, Mantura 2004, s. 91; Pacana i in. 2019, s. 337). Metodę kompleksowej i efektywnej analizy do identyfikacji źródła niezgodności stanowią zintegrowane techniki zarządzania jakością, czyli tzw. instrumenty zarządzania jakością, mające zastosowanie przy rozwiązywaniu problemów na różnych poziomach organizacji. Oprócz tego techniki te wspierają działania zarządcze poprzez dostarczanie odpowiednio przetworzonych informacji (Pacana, Czerwińska, Siwiec 2018, s. 7). Przy czym technika to celowy i racjonalny sposób postępowania, który jest oparty na teorii (Łuczak 2006, s. 268). Wspomnianymi technikami zarządzania jakością są m.in. metoda $5 \mathrm{~W} 2 \mathrm{H}$, diagram Pareto-Lorenza, diagram Ishikawy i metoda 5Why. Należy je stosować w sposób sekwencyjny, ponieważ stanowią swoje uzupełnienie (Pacana, Czerwińska, Siwiec 2018, s. 180). Metodą 5W2H możliwe jest przeanalizowanie i zdefiniowanie niezgodności (Pacana, Siwiec 2018, s. 421), za pomocą diagramu Pareto-Lorenza możliwe jest wykazanie, jaki udział w stosunku do całkowitej liczby zidentyfikowanych niezgodności stanowi liczba analizowanego typu niezgodności (Pacana, Czerwińska, Siwiec 2018, s. 186; Ulewicz 2003, s. 61). Następnie z wykorzystaniem diagramu Ishikawy możliwe jest zidentyfikowanie przyczyn potencjalnych niezgodności (Wolniak, Skotnicka 2008, s. 20; Wolniak 2017, s. 36), a spośród nich wybranie przyczyn głównych. Z kolei przyczyny główne są poddane dalszej analizie metodą 5 Why, po przeprowadzeniu której możliwe jest wskazanie przyczyny źródłowej niezgodności (Hamrol, Mantura 2004, s. 218; Hamrol 2018, s. 278). Wybór technik uwarunkowany był ich skutecznością przy niewielkim zaangażowaniu organizacyjno-ekonomicznym. Przyjęty wybór (ekspercki) w innych, podobnych przypadkach będzie można powtórzyć lub ewentualnie zmodyfikować, zmieniając skład i kolejność stosowanych technik.

Wiele przedsiębiorstw stosuje techniki zarządzania jakością do doskonalenia jakości produktów. Jednym z nich jest analizowane przedsiębiorstwo produkujące meble i fronty meblowe. Niestety stosowanie technik zarządzania jakością w tym przedsiębiorstwie było sporadyczne i bardziej uzależnione od pracownika niż problemu, który wystąpił. Jednym z takich problemów, do których dotychczas nie stosowano technik zarządzania jakością, była stosunkowo duża liczba uszkodzeń mechanicznych frontów meblowych zidentyfikowanych w przedsiębiorstwie produkującym meble i fronty meblowe zlokalizowanym na Podkarpaciu.

$\mathrm{W}$ analizowanym przedsiębiorstwie zidentyfikowano na frontach meblowych od stycznia do września 2018 roku sumarycznie 6971 wszystkich typów niezgodności. Jednym z typów niezgodności, które wielokrotnie identyfikowano, były uszkodzenia 
mechaniczne. Uszkodzenia mechaniczne frontów meblowych stanowiły dla przedsiębiorstwa istotny problem dotyczący jakości wyrobów, ponieważ dyskwalifikowały wyrób z procesu dalszej obróbki, a tym samym sprzedaży. Istotnym więc było przeanalizowanie problemu uszkodzeń mechanicznych frontów meblowych i wskazanie źródła ich powstania. W przedsiębiorstwie nie stosowano systemów zarządzania np. jakością lub środowiskiem, jak i nie prowadzono analiz za pomocą technik zarządzania jakością, umożliwiających identyfikację źródła niezgodności problemu, a przez to nie podejmowano adekwatnych działań, które mogłyby wyeliminować lub zminimalizować jego powstanie. Dlatego też zasadnym było zaproponowanie przedsiębiorstwu przeanalizowania problemu uszkodzeń mechanicznych technikami zarządzania jakością. Uznano, że zastosowanie sekwencji technik takich jak metoda $5 \mathrm{~W} 2 \mathrm{H}$, diagram Pareto-Lorenza, diagram Ishikawy i metoda 5Why umożliwi zarządzanie procesem zidentyfikowania źródła niezgodności uszkodzeń mechanicznych na froncie meblowym. Dlatego celem pracy jest wykazanie, że wybrane techniki zarządzania procesem zidentyfikowania źródła niezgodności mają zastosowanie do zidentyfikowania źródła uszkodzeń mechanicznych.

\section{Przedmiot i metodyka badań}

Przedmiotem badań był nieoklejony okleiną front meblowy. Analizowany front meblowy wykonany był z płyty MDF (ang. Medium Density Fibreboard) wyprodukowanej z włókien drzewnych.

Metodykę do przeanalizowania niezgodności powstałej na froncie meblowym (uszkodzenie mechaniczne) i zidentyfikowania źródła jej powstania stanowiła sekwencja technik zarządzania jakością. Technikami tymi były: metoda $5 \mathrm{~W} 2 \mathrm{H}$, diagram Pareto-Lorenza, diagram Ishikawy i metoda 5Why (Rysunek 1).

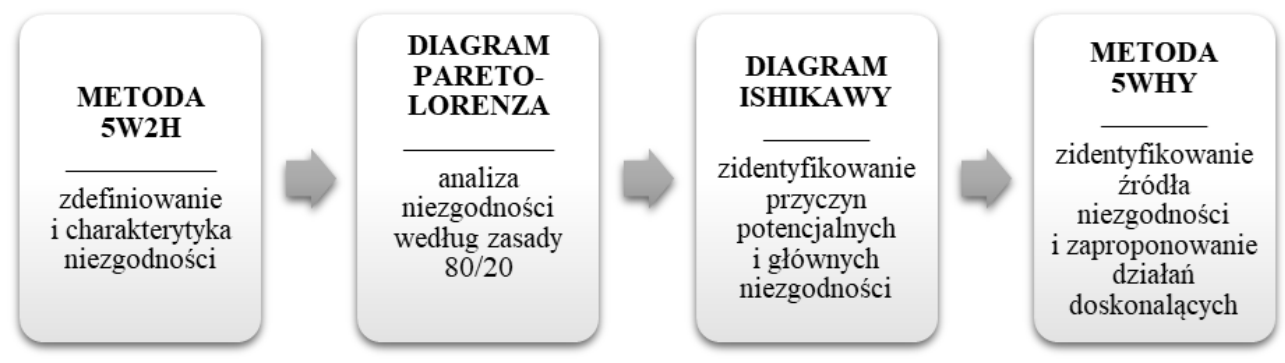

Rysunek 1. Proces analizy problemu technikami zarządzania jakością w celu zidentyfikowania źródła niezgodności

Źródło: Opracowanie własne

Wybór tych technik do analizy problemu uszkodzeń mechanicznych uwarunkowany był głównie ich skutecznością. Dodatkowo zwrócono uwagę na kolejność stosowanych metod, gdyż umożliwia to przeprowadzenie kompleksowej analizy problemu i wskazanie źródła jego powstania (Knop 2018, s. 127; Pacana, Czerwińska, Siwiec 2018, s. 179; Szczęśniak, Zasadzień, Wapienik 2012, s. 133). W tym przy- 
padku zastosowano ekspercki wybór technik zarządzania jakością. W innych przypadkach można go powielić lub ewentualnie modyfikować skład i kolejność stosowanych technik w zależności od specyfiki problemu.

\section{Metoda 5W2H}

Metoda 5W2H ma zastosowanie do szczegółowej analizy i scharakteryzowania problemu. Stanowi skuteczną technikę zarządzania jakością (Pacana, Siwiec 2018, s. 421). Dzięki niej możliwe jest zdefiniowanie oraz rozpoznanie problemu, a następnie przeanalizowanie go z uwzględnieniem najistotniejszych dla przedsiębiorstwa informacji. Metodyka przeprowadzenia analizy $5 \mathrm{~W} 2 \mathrm{H}$ polega na zadaniu sekwencyjnie siedmiu pytań adekwatnych do specyfiki problemu (Pacana i in. 2019, s. 110). Podczas analizy problemu uszkodzeń mechanicznych metodą $5 \mathrm{~W} 2 \mathrm{H}$ zadano sekwencyjnie siedem podstawowych pytań metodyki 5W2H (Rysunek 2), które znalazły zastosowanie do analizowanego problemu.

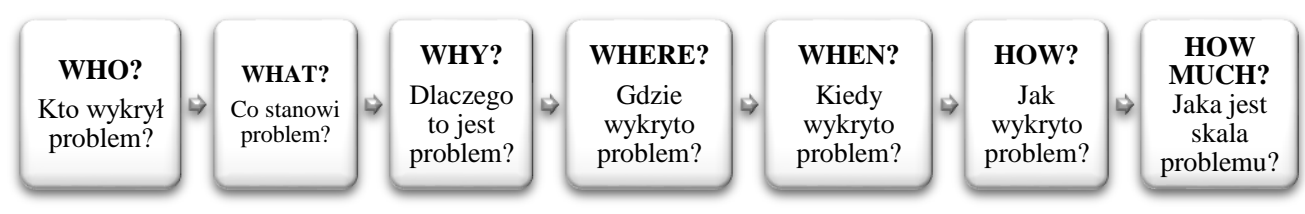

Rysunek 2. Proces analizy problemu metodą 5W2H

Źródło: Opracowanie własne

Po scharakteryzowaniu metodą 5W2H niezgodności uszkodzeń mechanicznych na frontach meblowych zastosowano diagram Pareto-Lorenza.

\section{Diagram Pareto-Lorenza}

Diagram Pareto-Lorenza, nazywany metodą 80/20 lub analizą Pareto-Lorenza, ma zastosowanie $\mathrm{w}$ badaniu, jaki udział stanowi analizowany typ niezgodności w stosunku do pozostałych typów niezgodności (tj. zasada 80/20: 80\% skutków powoduje 20\% przyczyn) (Ulewicz 2003, s. 61; Wolniak 2017, s. 36). Wykorzystując diagram Pareto-Lorenza można zastosować inną proporcję, tak aby było możliwe adekwatnie do problemu wskazanie proporcji liczby skutków do liczby przyczyn ich powstania (Pacana, Czerwińska, Siwiec 2018, s. 186; Ulewicz 2003, s. 61). Celowością zastosowania diagramu Parto-Lorenza do analizy niezgodności uszkodzeń mechanicznych było ukazanie liczby uszkodzeń mechanicznych w stosunku do liczby pozostałych typów niezgodności. W pierwszym etapie przeprowadzenia analizy liczby uszkodzeń mechanicznych na frontach meblowych za pomocą diagramu Pareto-Lorenza zebrano liczbę wszystkich typów niezgodności zidentyfikowanych w organizacji za analizowany okres (tj. od stycznia do września 2018 r.). Obliczono skumulowaną liczbę poszczególnych typów niezgodności, jak i skumulowaną procentową liczbę wszystkich typów niezgodności. W drugim etapie sporządzono wykres Pareto-Lorenza, w którym oznaczono typy niezgodności, ich liczbę oraz ich 
skumulowaną liczbę wystąpienia $\mathrm{w}$ analizowanym okresie czasu. $\mathrm{W}$ trzecim etapie dokonano analizy zebranych danych zgodnie z zasadą 80/20 (dobraną adekwatnie do liczby uszkodzeń mechanicznych), po czym wskazano, jaki udział procentowy stanowi liczba uszkodzeń mechanicznych w stosunku do pozostałej liczby typów niezgodności zidentyfikowanych $\mathrm{w}$ organizacji w ciągu analizowanych 9 miesięcy. W kolejnym etapie metodyki dokonano analizy problemu diagramem Ishikawy, aby zidentyfikować przyczyny potencjalne.

\section{Diagram Ishikawy}

Diagram Ishikawy, nazywany diagramem przyczynowo-skutkowym lub diagramem rybiej ości, umożliwia zidentyfikowanie przyczyn potencjalnych problemu i wskazanie spośród nich przyczyn głównych problemu (Hamrol, Mantura 2004, s. 218; Kowalik 2018, s. 15). Diagram pozwala na dokonanie analizy problemu i ukazanie w sposób graficzny przyczyn mających wpływ na jego powstanie (Hamrol 2018, s. 278; Ulewicz 2003, s. 62). Stosując diagram Ishikawy do analizy problemu uszkodzeń mechanicznych na frontach meblowych, zastosowano spośród podstawowych kategorii Ishikawy, tj. 5M+E, wybranych i adekwatnych do analizowanego problemu 5 podstawowych kategorii diagramu Ishikawy, tj. człowiek, metoda, maszyna, zarządzanie i środowisko (Pacana, Czerwińska, Siwiec 2018, s. 66; Siwiec, Pacana 2019, s. 34). Do każdej kategorii przyporządkowano przyczyny potencjalne. Spośród przyczyn potencjalnych wybrano przyczyny główne, które poddano dalszej analizie metodą 5 Why.

\section{Metoda 5Why}

Metoda 5Why (Why-Why) jest metodą, za pomocą której możliwe jest zidentyfikowanie źródła problemu (Wolniak 2017, s. 35). W przypadku analizowanego problemu uszkodzeń mechanicznych na frontach meblowych zidentyfikowano zdefiniowany problem (uszkodzenia mechaniczne). Kolejno przyporządkowano wskazane przyczyny główne problemu zidentyfikowane za pomocą analizy diagramem Ishikawy. Sekwencyjnie zadawano pytanie „Dlaczego?” (ang. „Why?”) do każdej przyczyny pośredniej, aż do zidentyfikowania przyczyny źródłowej (Pacana, Siwiec, Bednárová 2019, s. 338; Pacana i in. 2019, s. 111). Po wskazaniu źródła powstania uszkodzeń mechanicznych na frontach meblowych zaproponowano adekwatne do źródła problemu działania doskonalące, $w$ celu wyeliminowania lub zminimalizowania ich powstania.

\section{Wyniki}

Przeanalizowano liczbę uszkodzeń mechanicznych frontów meblowych (tj. 285 sztuk uszkodzonych mechanicznie frontów meblowych od stycznia do września 2018 roku) zidentyfikowanych w przedsiębiorstwie produkującym meble i fronty meblowe zlokalizowanym na Podkarpaciu. Zidentyfikowane uszkodzenie mechaniczne na froncie meblowym przedstawiono na Rysunku 3. 


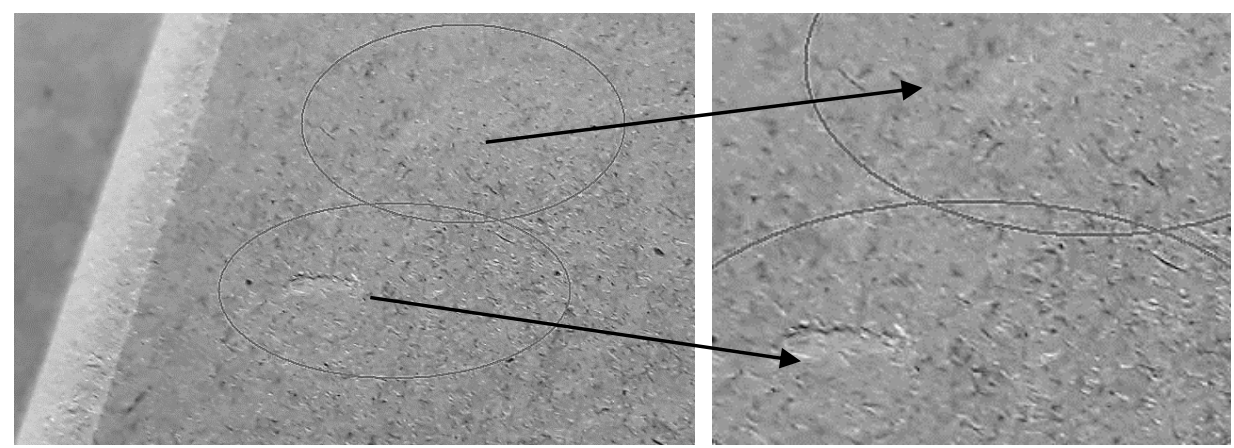

Rysunek 3. Zidentyfikowane szkodzenia mechaniczne na froncie meblowym

Źródło: Opracowanie własne

Dokonano analizy problemu uszkodzenia mechanicznego frontu meblowego za pomocą metody 5W2H (Tabela 1).

Tabela 1. Analiza problemu uszkodzeń mechanicznych metodą 5W2H

\begin{tabular}{|c|c|c|}
\hline \multicolumn{3}{|c|}{ METODA 5W2H } \\
\hline \multicolumn{2}{|r|}{ Pytanie } & Odpowiedź \\
\hline Who? & Kto wykrył problem? & Pracownik na stanowisku obróbki frontu \\
\hline What? & Co stanowi problem? & Uszkodzenie mechaniczne frontu meblowego \\
\hline Why? & $\begin{array}{l}\text { Dlaczego jest to } \\
\text { problem? }\end{array}$ & Niezgodność dyskwalifikująca wyrób \\
\hline Where? & $\begin{array}{l}\text { Gdzie wykryto } \\
\text { problem? }\end{array}$ & $\mathrm{Na}$ froncie meblowym \\
\hline When? & $\begin{array}{l}\text { Kiedy wykryto } \\
\text { problem? }\end{array}$ & Podczas kontroli jakości \\
\hline How? & Jak wykryto problem? & Kontrolą wizualną \\
\hline How much? & $\begin{array}{l}\text { Jaka jest skala } \\
\text { problemu? }\end{array}$ & $\begin{array}{l}285 \text { sztuk frontów uszkodzonych } \\
\text { mechanicznie (od stycznia do września } 2018 \text { r.) }\end{array}$ \\
\hline
\end{tabular}

Źródło: Opracowanie własne

Kolejno przeanalizowano całkowitą liczbę uszkodzonych mechanicznie frontów w stosunku do liczby pozostałych typów niezgodności, które odnotowano w przedsiębiorstwie od stycznia do września 2018 roku. W tym celu sporządzono zgodnie z metodyką analizy Pareto-Lorenza zestawienie liczby wszystkich niezgodności, które ukazano w formie stabelaryzowanej (Tabela 2). 
Tabela 2. Fragment zestawienia liczby wszystkich niezgodności zidentyfikowanych $w$ przedsiębiorstwie w okresie od stycznia do września 2018 roku

\begin{tabular}{|c|c|c|c|c|}
\hline Lp. & Typ niezgodności & $\begin{array}{c}\text { Liczba } \\
\text { niezgodno- } \\
\text { ści [szt.] }\end{array}$ & $\begin{array}{c}\text { Skumulowana } \\
\text { liczba } \\
\text { niezgodności } \\
\text { [szt.] }\end{array}$ & $\begin{array}{c}\text { Skumulowana } \\
\text { liczba } \\
\text { niezgodności } \\
{[\%]}\end{array}$ \\
\hline 1. & Niekompletna dostawa & 1659 & 1659 & $24 \%$ \\
\hline 2. & Kropki & 1329 & 2988 & $43 \%$ \\
\hline 3. & Zmarszczki & 793 & 3781 & $54 \%$ \\
\hline 4. & Wada folii & 696 & 4477 & $64 \%$ \\
\hline 5. & Błędne oczyszczenie & 604 & 5081 & $73 \%$ \\
\hline 6. & Wada płyty & 476 & 5557 & $80 \%$ \\
\hline 7. & Niedociągnięta folia & 460 & 6017 & $86 \%$ \\
\hline 8. & Uszkodzenie mechaniczne & 285 & 6302 & $90 \%$ \\
\hline 9. & Pękniecie folii w prasie & 149 & 6451 & $93 \%$ \\
\hline 10. & Odklejenie folii & 138 & 6589 & $95 \%$ \\
\hline 11. & Wada frezowania & 79 & 6668 & $96 \%$ \\
\hline 12. & Zacieki wodne & 67 & 6735 & $97 \%$ \\
\hline 13. & $\begin{array}{c}\text { Ścieranie farby } \\
\text { (tzw. przebłyszczenie) }\end{array}$ & 56 & 6791 & $97 \%$ \\
\hline 14. & Niezgodny wymiar & 55 & 6846 & $98 \%$ \\
\hline 15. & Niezgodny kolor & 51 & 6897 & $99 \%$ \\
\hline 16. & Błędne naniesienie kleju & 43 & 6940 & $100 \%$ \\
\hline 17. & Niezgodny profil & 19 & 6959 & $100 \%$ \\
\hline 18. & Brak w magazynie & 8 & 6967 & $100 \%$ \\
\hline 19. & Błędnie rozpisana formatka & 4 & 6971 & $100 \%$ \\
\hline \multicolumn{2}{|r|}{ Suma } & 6971 & & \\
\hline
\end{tabular}

Źródło: Opracowanie własne

Na podstawie zestawienia liczby wszystkich niezgodności sporządzono wykres Pareto-Lorenza i dokonano jego analizy, wykorzystując adekwatnie do problemu liczby uszkodzeń mechanicznych zasadę 80/20 (Rysunek 4). 


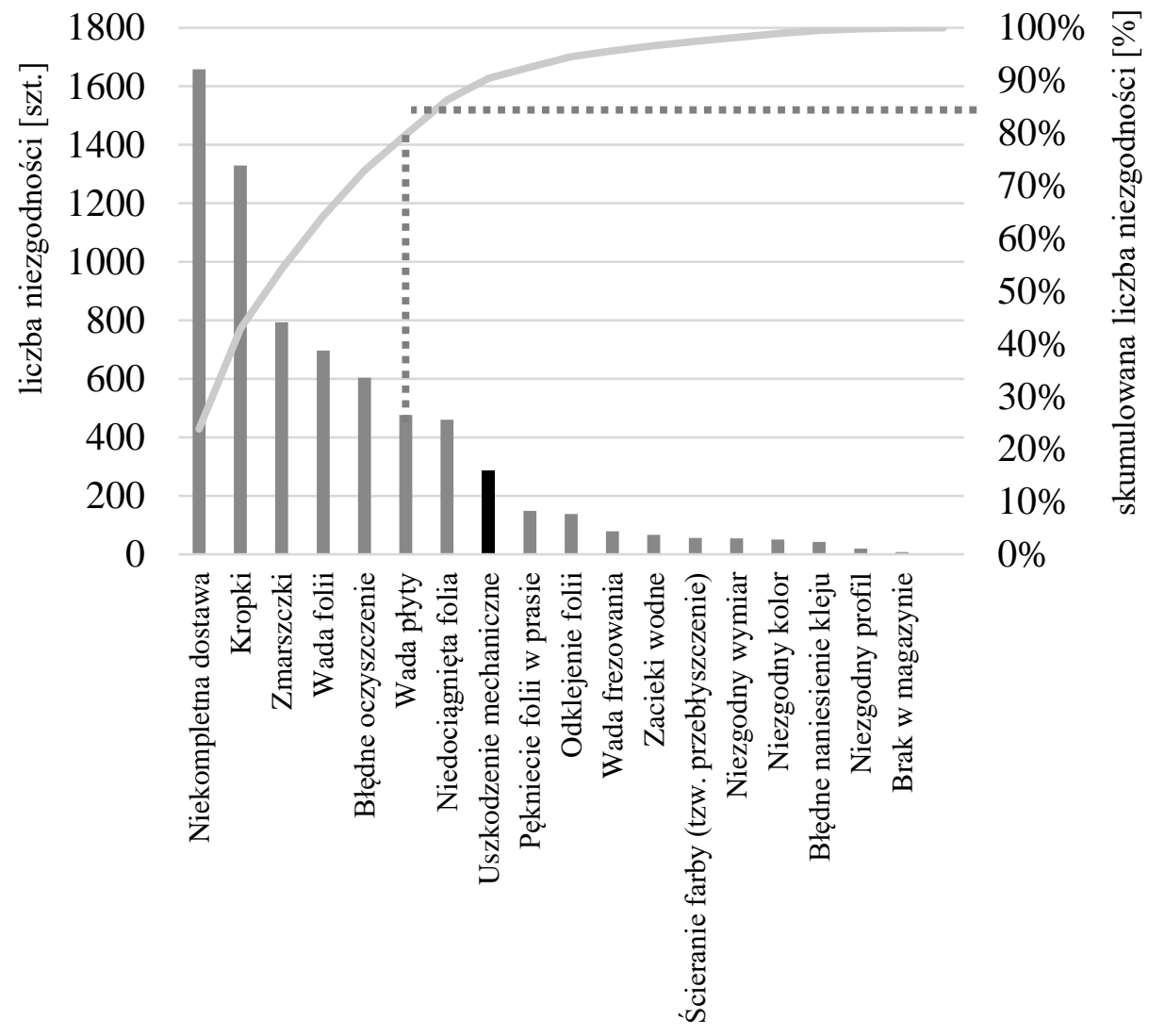

typ niezgodności

liczba niezgodności [szt.] skumulowana liczba niezgodności [\%]

Rysunek 4. Diagram Pareto-Lorenza dla typów niezgodności zidentyfikowanych w przedsiębiorstwie od stycznia do września 2018 roku

Źródło: Opracowanie własne

Za pomocą diagramu Pareto-Lorenza wykazano, że liczba uszkodzeń mechanicznych stanowiła $10 \%$ z całkowitej liczby wszystkich zidentyfikowanych w przedsiębiorstwie typów niezgodności (w okresie od stycznia do września 2018 roku).

Kolejno przeprowadzono dalszą analizę problemu uszkodzenia mechanicznego frontu meblowego za pomocą diagramu Ishikawy (Rysunek 5). 


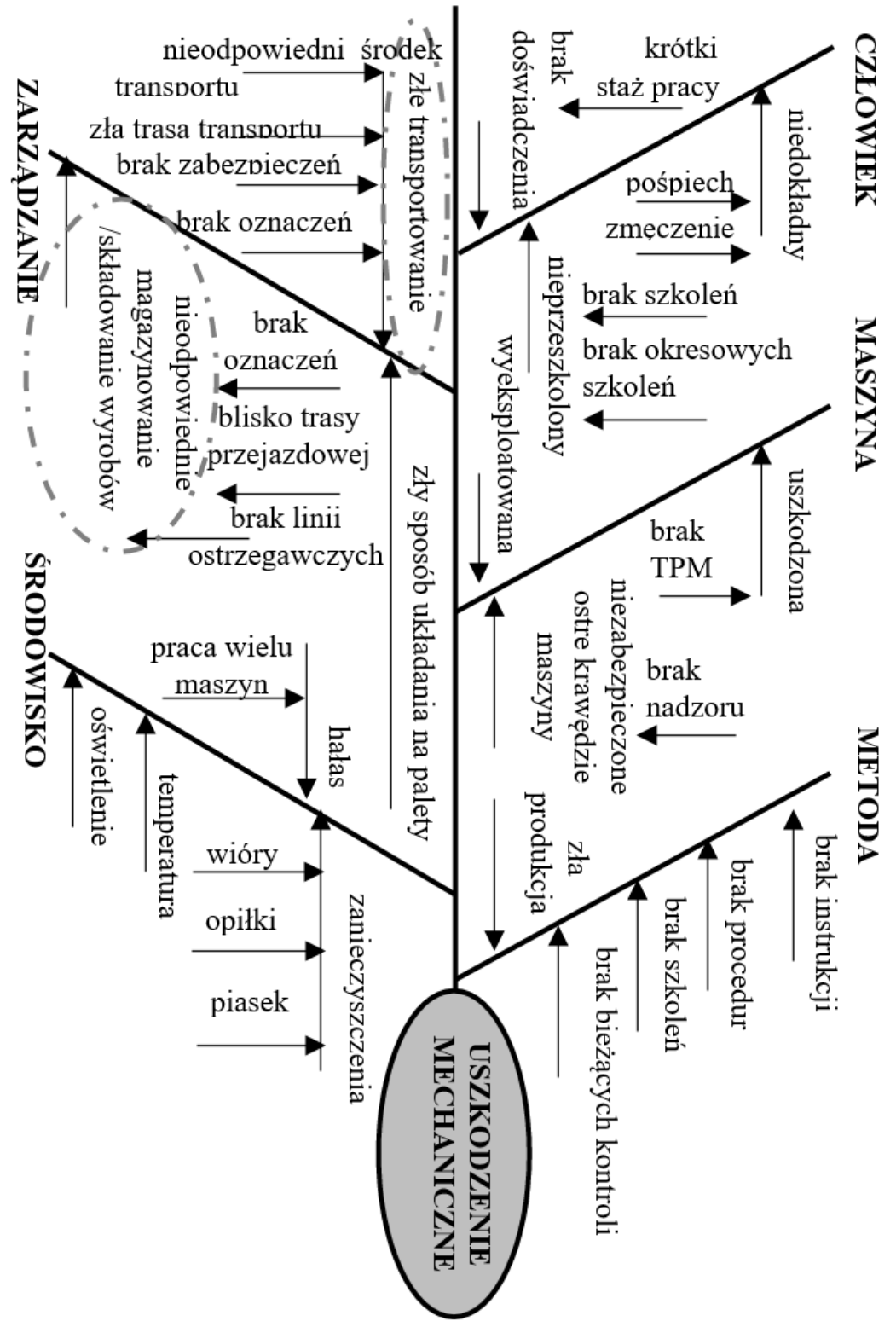

Rysunek 5. Diagram Ishikawy dla problemu uszkodzeń mechanicznych

Źródło: Opracowanie własne

Spośród potencjalnych przyczyn problemu uszkodzeń mechanicznych wybrane zostały dwie przyczyny główne, $\mathrm{tj}$. nieodpowiednie magazynowanie/składowanie wyrobów oraz złe transportowanie.

Aby wskazać przyczynę źródłową problemu uszkodzeń mechanicznych, przeprowadzono analizę metodą 5Why (Rysunek 6 ). 


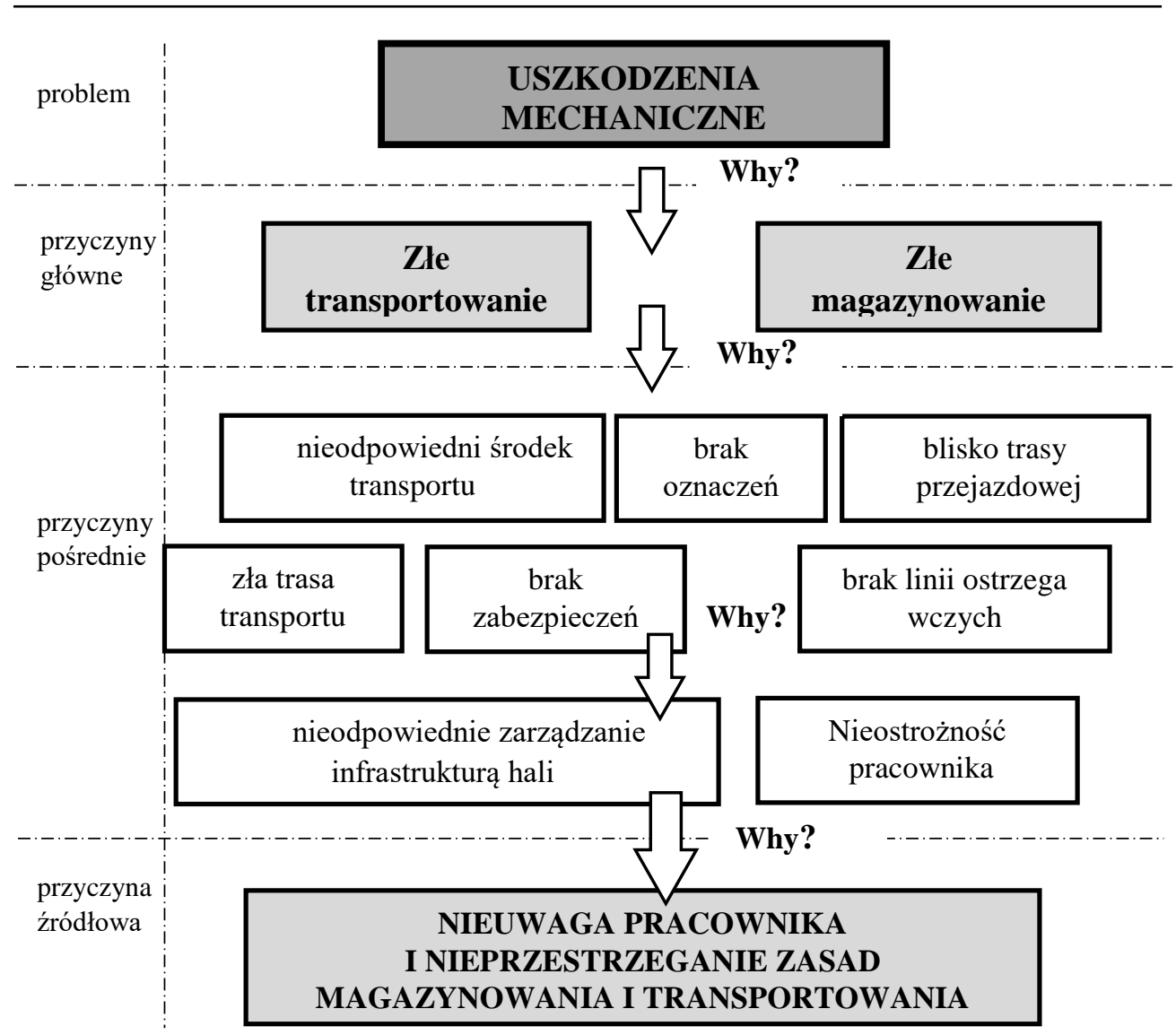

Rysunek 6. Metoda 5Why - identyfikacja źródła uszkodzeń mechanicznych

Źródło: Opracowanie własne

Po przeprowadzeniu analizy metodą 5 Why wywnioskowano, że źródłem uszkodzeń mechanicznych była nieuwaga pracowników i nieprzestrzeganie zasad magazynowania i transportowania wyrobów.

W celu wyeliminowania lub zminimalizowania powstawania uszkodzeń mechanicznych (powstających na frontach meblowych) uznano, że należy przeanalizować sposób zarządzania infrastrukturą hali i magazynu. W przypadku braku oznaczeń (m.in. linie ostrzegawcze, tabliczki, etykiety) należy je wprowadzić i ponownie przeszkolić pracowników z zasad magazynowania i transportowania wyrobów.

\section{Podsumowanie}

Zarządzanie jakością wyrobów to dokonywanie ich jakościowych kontroli w celu wykrycia ewentualnych niezgodności, jak i identyfikowanie źródła tych niezgodności. Dlatego też niezgodności te powinny być analizowane w drodze projakościowego zarządzania, czyli w formie procesu, gdzie odpowiednio dobrane i zintegrowane techniki 
zarządzania jakością wykorzystywane są do identyfikowania źródła niezgodności. $Z$ kolei poprawne wskazanie źródła niezgodności przyczynia się do podjęcia właściwych działań, dzięki którym możliwe jest wyeliminowanie lub zredukowanie powstania tych niezgodności. To szczególnie istotne $\mathrm{w}$ przypadku przedsiębiorstw, w których występuje duża liczba różnych typów niezgodności, a źródło ich powstania nie jest zidentyfikowane, dlatego ważne jest projakościowe zarządzanie.

Problem z dużą liczbą niezgodności (uszkodzeń mechanicznych na frontach meblowych) powstał w przedsiębiorstwie zlokalizowanym na Podkarpaciu. W firmie zidentyfikowano ponad 280 sztuk frontów meblowych uszkodzonych mechanicznie (od stycznia do września 2018 roku). W wybranym przedsiębiorstwie nie wskazano źródła powstania tych uszkodzeń mechanicznych, przez to nie podejmowano działań, które mogłyby zapobiec ich powstawaniu. Uznano, że zastosowanie sekwencji technik - metoda 5W2H, diagram Pareto-Lorenza, diagram Ishikawy i metoda 5Why - umożliwi zarządzanie procesem zidentyfikowania źródła niezgodności uszkodzeń mechanicznych na froncie meblowym. Dlatego istotnym było zaproponowanie przedsiębiorstwu przeprowadzenia analizy niezgodności technikami zarządzania jakością. Cel pracy stanowiło wykazanie, że wybrane techniki zarządzania procesem zidentyfikowania źródła niezgodności mają zastosowanie do wskazania źródła uszkodzeń mechanicznych. Technikami tymi były zastosowane sekwencyjnie: metoda 5W2H, diagram Pareto-Lorenza, diagram Ishikawy i metoda 5Why.

W pierwszym etapie przeanalizowano i zdefiniowano problem uszkodzeń mechanicznych na frontach meblowych za pomocą metody 5W2H. Następnie, wykorzystując diagram Pareto-Lorenza, ukazano udział procentowy liczby uszkodzeń mechanicznych w stosunku do liczby pozostałych typów niezgodności, gdzie liczba uszkodzeń mechanicznych stanowiła $10 \% \mathrm{z}$ całkowitej liczby wszystkich zidentyfikowanych w przedsiębiorstwie typów niezgodności (w okresie od stycznia do września 2018 roku). Dalej, dokonując analizy uszkodzeń mechanicznych diagramem Ishikawy, wskazano przyczyny potencjalne niezgodności, spośród których wybrano dwie przyczyny główne, tj. nieodpowiednie magazynowanie/składowanie wyrobów oraz złe transportowanie. W ostatnim etapie analizy za pomocą metody 5 Why zidentyfikowano źródło powstania uszkodzeń mechanicznych, którym była nieuwaga pracowników oraz nieprzestrzeganie zasad magazynowania i transportowania wyrobów. Po przeanalizowaniu problemu dużej liczby uszkodzeń mechanicznych wykazano, że zastosowanie technik zarządzania procesem w sposób sekwencyjny umożliwia przeprowadzenie kompleksowej i efektywnej analizy niezgodności w celu zidentyfikowania źródła jej powstania. Wybór tych technik do analizy problemu uszkodzeń mechanicznych frontów meblowych uwarunkowany był ich skutecznością przy niewielkim zaangażowaniu organizacyjno-ekonomicznym, przez co mogą mieć zastosowanie do analizy innych problemów w przedsiębiorstwach. Dodatkowo, po przeprowadzeniu analizy problemu, wykazano, że metoda zintegrowanych technik zarządzania jakością występujących jako proces $(5 \mathrm{~W} 2 \mathrm{H}$, diagram Pareto-Lorenza, diagram Ishikawy i metoda 5 Why) była skuteczna w identyfikowaniu źródła niezgodności. Wykazano, że techniki zarządzania procesem identyfikacji źródła niezgodności mają zastosowanie w identyfikacji źródła niezgodności uszkodzeń mechanicznych na froncie meblowym. W związku z czym przyjęty wybór ekspercki 
w innych, podobnych przypadkach będzie można powtórzyć lub ewentualnie zmodyfikować, zmieniając skład i kolejność stosowanych technik. Dlatego też zaproponowane techniki zarząazzania procesem mogą być praktykowane do identyfikacji źródeł niezgodności problemów w przedsiębiorstwach produkcyjnych i usługowych.

\section{Literatura}

1. Chądzyńska M., Klimecka-Tatar D. (2017), Identyfikacja występujących przyczyn niezgodności za pomoca diagramu Pareto-Lorenza - produkcja wyrobów kaletniczych, „Archiwum Wiedzy Inżynierskiej”, nr 2(1).

2. Frąś J., Frąś T., Frą́s M. (2017), Model instrumentów zarządzania jakościa w procesach produkcyjnych, „Problemy Nauk Stosowanych”, nr 6.

3. Hamrol A. (2018), Zarzadzanie i inżynieria jakości, Wydawnictwo Naukowe PWN, Warszawa.

4. Hamrol A., Mantura W. (2004), Zarzadzanie jakościa. Teoria i praktyka, Wydawnictwo Naukowe PWN, Warszawa.

5. Jankowiak R. (2008), Instrumenty zarządzania jakościa, „Zeszyty Naukowe Wydziału Nauk Ekonomicznych Politechniki Koszalińskiej”, nr 12.

6. Knop K. (2018), Analiza problemów w systemie zarządzania produkcja w wybranym przedsiębiorstwie, „Quality Production Improvement”, No. 2(9).

7. Kowalik K. (2018), Diagram Ishikawy w teorii i praktyce zarzadzania jakościa, „Archiwum Wiedzy Inżynierskiej”, nr 3(1).

8. Łuczak J. (2006), Metody i techniki zarzadzania jakościa, [w:] Łańcucki J. (red.), Podstawy kompleksowego zarządzania jakościa TQM, Wydawnictwo Akademii Ekonomicznej w Poznaniu, Poznań.

9. Pacana A., Czerwińska K., Siwiec D. (2018), Narzędzia i wybrane metody zarządzania jakością. Teoria i praktyka, Oficyna Wydawnicza Stowarzyszenia Menedżerów Jakości i Produkcji, Częstochowa.

10. Pacana A., Siwiec D. (2018), Analiza problemu wyrobów niezgodnych z wykorzystaniem instrumentów zarządzania jakością, ,Zeszyty Naukowe Politechniki Śląskiej. Organizacja i Zarządzanie", nr 131.

11. Pacana A., Siwiec D., Bednárová L. (2019), Analysis of the Incompatibility of the Product with Fluorescent Method, „Metalurgija”, No. 58(3-4).

12. Pacana A., Siwiec D., Bednárowá L., Hajduová Z. (2019), Wybrane metody zarządzania jakościa stosowane do oceny druku etykiet, „Przemysł Chemiczny”, nr 98(1).

13. Rachwał A., Wolniak R. (2018), Wplyw niezgodności systemowych na realizację procesu spawania, ,Zeszyty Naukowe Politechniki Śląskiej. Organizacja i Zarządzanie”, nr 118.

14. Rosak-Szyrocka J. (2017), Analiza i doskonalenie jakości na przykładzie przedsiębiorstwa produkcyjnego, ,Zeszyty Naukowe Politechniki Częstochowskiej. Zarządzanie”, nr 28(1).

15. Siwiec D., Bednárová L., Pacana A., Zawada M., Rusko M. (2019), Wspomaganie decyzji $w$ procesie doboru penetrantów fluorescencyjnych do przemysłowych badań nieniszczacych, „Przemysł Chemiczny”, nr 98(10).

16. Siwiec D., Pacana A. (2019), The Use of Quality Management Techniques to Analyse the Cluster of Porosities on the Turbine Outlet Nozzle, „Production Engineering Archives”, Vol. 24.

17. Sobocha-Stanuch J. (2014), Koncepcja podejścia procesowego w zarzadzaniu akademickimi bibliotekami naukowymi. Wstępna identyfikacja procesów na przykładzie Biblioteki Głównej AGH w Krakowie, „Zeszyty Naukowe Politechniki Częstochowskiej. Zarządzanie”, nr 14.

18. Szczęśniak B., Zasadzień M., Wapienik Ł. (2012), Zastosowanie analizy Pareto oraz diagramu Ishikawy do analizy przyczyn odrzutów w procesie produkcji silników elektrycznych, „Zeszyty Naukowe Politechniki Śląskiej. Organizacja i Zarządzanie”, nr 63a. 
19. Ulewicz R. (2003), Quality Control System in Production of the Castings from Spheroid Cast Iron, „Metalurgija”, Vol. 42(1).

20. Wolniak R. (2017), Application Methods for Analysis Car Accident in Industry on the Example of Power, „Support Systems in Production Engineering”, Vol. 6(4).

21. Wolniak R., Skotnicka B. (2008), Metody i narzędzia zarządzania jakościa. Teoria i praktyka, Wydawnictwo Politechniki Śląskiej, Gliwice.

\title{
USE OF MANAGEMENT TECHNIQUES TO IDENTIFY SOURCE OF NON-CONFORMITY MECHANICAL DAMAGE
}

\begin{abstract}
Analyzing product nonconformity and also the root of its occurrence is especially important in product quality management. Such nonconformities have occurred in the production enterprise localized in Podkarpacie. It was not possible to routinely identify the source of this damage. For this reason, it was decided that using management techniques, i.e. 5W2H method, Pareto-Lorenz diagram, Ishikawa diagram and 5Why method, to identify the source of incompatibilities of mechanical damages on furniture fronts. Therefore, this work aims to show that the selected management techniques can be applied to identify the source of mechanical damage. The incompatibility was analyzed and defined using the $5 \mathrm{~W} 2 \mathrm{H}$ method. The Pareto-Lorenz diagram showed the share of mechanical damage, while the use of Ishikawa diagram demonstrated the potential and main causes of nonconformity, i.e. inappropriate storage of the product and transport. The 5 Why method was used to identify the root of mechanical damages, which was the inattention of employees and non-compliance with the rules for storing and transporting products. It was shown, that using the selected management techniques makes it possible to identify the source of mechanical damage on furniture fronts. The proposed method can be practiced in various enterprises to analyze the quality problems of products.
\end{abstract}

Keywords: quality, mechanical damages, mechanical engineering, quality management 